\title{
IMPLEMENTASI DANA DESA UNTUK KEGIATAN KEBUDAYAAN GUMELARING KADIPATEN DI DESA PURWODADI KECAMATAN BARAT KABUPATEN MAGETAN
}

\author{
Yusuf Adam Hilman1 ${ }^{*}$, Fachrudin Cholli1 ${ }^{2}$ \\ ${ }^{12}$ Program Studi Ilmu Pemerintahan, FISIP, Universitas Muhammadiyah Ponorogo, Indonesia \\ adam_hilman@umpo.ac.id
}

\begin{abstract}
The purpose of this study is to describe the implementation of village funds for cultural activities in Purwodadi Village, West Sub-district, Magetan Regency. This research uses a descriptive qualitative approach and its data sources are primary and secondary. Data collection techniques by interview, observation and document notes. The results of this study indicate that the committee as the organizer of the duchy gumelaring event and the purwodadi village party as the provider of the land are intertwined. The results of the holding of the duchy gumelaring for the committee is to preserve the culture and history that must be preserved and the results obtained by the Purwodadi village by holding a duchy gumelaring event that is promoting the village as a tourist village and inviting the community to participate in mutual assistance in preserving assets owned the village. normatively and administratively The management of village fund allocation is done well, but in substance it has not touched the true meaning of implementation.
\end{abstract}

Keywords: Implementation, Village Fund, Culture

\begin{abstract}
Abstrak
Tujuan penelitian ini adalah untuk mendeskrupsikan Tentang implementasi dana desa untuk kegiatan kebudayaan Di desa purwodadi kecamatan barat kabupaten magetan. Penelitian ini menggunakan pendekatan kualitatif deskriptif dan sumber datanya bersifat primer dan sekunder. Teknik pengumpulan data dengan cara wawancara, obserfasi dan catatan dokumen. Hasil penelitian ini menunjukkan bahwa panitia selaku penyelenggara Acara gumelaring kadipaten dan pihak desa purwodadi selaku penyedia lahan terjalin baik. Hasil dari di adakannya gumelaring kadipaten bagi panitia yaitu bisa melestarikan budaya dan juga sejarah yang patut di lestarikan dan hasil yang di dapat Pihak desa purwodadi dengan diadakannya acara gumelaring kadipaten yaitu mempromosikan desanya sebagai desa wisata dan mengajak masyarakat ikut gotong royong dalam menjaga aset yang di miliki desa tersebut. secara normatif dan administratif Pengelolaan alokasi dana desa di lakukan dengan baik, namun secara substansi masih belum menyentuh makna implementasi yang sesungguhnya.
\end{abstract}

Kata kunci: Implementasi, Dana Desa, Kebudayaan

\section{A. PENDAHULUAN}

Keberadaan desa secara yuridis formal diakui dalam Undang-Undang Nomr 32 Tahun 2004 tentang Pemerintahan Daerah dan Peraturan Pemerintah Nomor 72 tahun 2005 tentang Desa. Berdasarkan ketentuan tersebut Desa diberi pengertian sebagai kesatuan masyarakat hukum yang memiliki batas-batas wilayah yang berwenang untuk mengatur dan mengurus kepentingan masyarakat setempat berdasarkan asal usul dan adat istiadat setempat yang diakui dan dihormati dalam sistem Pemerintahan Negara Kesatuan Republik Indonesia. (Wisakti, 2008)

Otonomi daerah yang muncul mengakibatkan terjadinya pergeseran sistem pemerintahan yang bercorak sentralisasi mengarah kepada sistem pemerintahan yang desentralisasi. Sistem pemerintahan desentralisasi adalah sistem yang memberikan keleluasaan pada daerah dalam mewujudkan daerah 
otonom yang luas dan bertanggung jawab, untuk mengatur dan mengurus kepentingan masyarakat setempat. Tujuan diberikannya otonomi pada daerah pada dasarnya adalah untuk meningkatnya daya dan hasil guna penyelenggaraan pemerintah daerah, terutama dalam pelaksanaan pembangunan dan pelayanan terhadap masyarakat serta meningkatkan pembinaan kesatuan politik dan kesatuan bangsa (Hasman. 2015)

Undang-undang Nomor 6 Tahun 2014 Tentang Desa, wilayah otonom dari pemerintah daerah adalah desa, yaitu kesatuan masyarakat hukum yang memiliki batas wilayah yang berwenang untuk mengatur dan mengurus urusan pemerintahan, kepentingan masyarakat setempat berdasarkan prakarsa masyarakat, hak asal usul, dan atau hak tradisional yang diakui dan dihormati dalam sistem pemerintahan Negara Kesatuan Republik Indonesia. Hal ini menjadikan desa memiliki kewenangan tersendiri dalam mengatur wilayahnya guna mendukung penyelengaraan pemerintahan desa. Pada pasal 19 juga diatur tentang kewenangan desa yang meliputi: kewenangan berdasarkan hak asal usul, kewenangan lokal berskala desa, kewenangan yang ditugaskan oleh pemerintah, pemerintah daerah provinsi, atau pemerintah daerah Kabupaten/Kota dan kewenangan lain yang ditugaskan oleh pemerintah, pemerintah daerah provinsi, atau pemerintah daerah Kabupaten/Kota sesuai dengan ketentuan peraturan perundang-undangan (Hertati dan Arif, 2018)

Salah satu contoh dari keleluasaan mengatur dan mengurus urusan pemerintahan yaitu, pemerintah desa bebas mengarahkan kemana alokasi dana desa digunakan. Dalam pasal 1 angka 2 Peraturan pemerintah Nomor 8 Tahun 2016 memberikan definisi dana desa, yaitu dana yang bersumber dari Anggaran Pendapatan dan Belanja Negara yang diperuntukkan bagi desa yang ditransfer melalui Anggaran Pendapatan dan Belanja Daerah Kabupaten/Kota dan digunakan untuk membiayai penyelenggaraan pemerintahan, pelaksanaan pembangunan, pembinaan kemasyarakatan, dan pemberdayaan masyarakat (Garis, 2017)

Alokasi dana desa sangat penting dalam pembiayaan pengembangan wilayah tertinggal dalam suatu sistem wilayah pengembangan. Salah satunya adalah alokasi dana desa dalam kegiatan gumelaring kadipaten. Gumelaring kadipaten merupakan budaya berbentuk festival yang disuguhkan guna menjadi destinasi wisata. Festival Gumelaring Kadipaten yang berasal dari Desa Purwodadi Kecamatan Barat Kabupaten Magetan menyuguhkan seni yang begitu indah, sehingga menjadi daya tarik tersendiri bagi para wisatawan untuk turut hadir saat berlangsungnya acara. Tujuan kegiatan ini diselenggarakan selain melestarikan budaya bangsa, juga sebagai sarana dalam rangka menggerakkan perekonomian masyarakat. Disamping itu, dengan kegiatan ini diharapkan kedepannya Desa Purwodadi bisa disahkan menjadi destinasi wisata oleh Pemerintah Kabupaten Magetan.

Implementasi merupakan sebuah realisasi dari perencanaan yang telah disusun. Jika dilaksanakan dengan baik dan tepat maka tujuan yang diharapkan akan tercapai sesuai renana, namun jika dilaksanakan tidak sebagaimana mestinya maka tujuan yang diharapkan tidak berjalan sebagaimana mestinya. Implementasi dalam pembangunan desa yang diatur dalam Peraturan Pemerintah Nomor 43 Tahun 2004 tentang implementasi desa dalam Pasal 121 ayat 1, 4, dan 5 yang menjelaskan:

a. Kepala desa mengkoordinasikan kegiatan pembangunan desa yang dilaksanakan oleh perangkat desa dan/ unsur masyarakat.

b. 4) Implementasi pembangunan sebagaimana dimaksud pada ayat 1 menyampaikan laporan implementasi pembangunan kepada kepala Desa dalam forum musyawarah desa.

c. 5) Masyarakat desa berpatisipasi dalam musyawarah desa sebagaimana dimaksud pada ayat 4 untuk menanggapi laporan implementasi pembangunan desa.

Menurut Winarno, bahwa ada empat faktor yang mempengaruhi proses implementasi antara lain:

a. Komunikasi antar organisasi dan kegiatan pelaksanaan

b. Karateristik-kareteristik badan pelaksana

94 | Barista: Jurnal Kajian Bahasa dan Pariwisata, Volume 6 Nomor 2, 2019: 93-100 
c. Lingkungan ekonomi, sosial dan politik yang mempengaruhi yuridiksi atau organisasi implementasi

d. Kecenderungan para pelaksana terhadap ukuran-ukuran dasar dan tujuan (Suparman dkk, 2014).

Implementasi yang kurang berhasil seringkali kurang memperhatikan atau membutuhkan mekanisme dan prosedur lembaga, sehingga pejabat-pejabat tinggi (Pemkab) kurang dapat meningkatkan kemungkinan bahwa para pelaksana kurang dapat bertindak secara konsisten dengan ukuran-ukuran dasar dan tujuan kebijaksanaan. Kontek implementasi kebijakan Pemerintah, menuntut adanya perubahan atau inovasi terhadap peran pemerintah dari pelaksana menjadi fasilitator, sehingga kiranya dapatmemberikan intruksi, terhadap pelayanan masyarakat, mengatur menjadi memberdayakan dan bekerja semata-mata untuk memenuhi aturan menjadi bekerja untuk mewujudkan misi (Suparman dkk, 2014).

Implementasi program merupakan satu tahap penting dalam proses program, yaitu suatu proses untuk membuat suatu yang formal bisa terselenggara di lapangan oleh aktor sehingga memberi hasil. Menurut teori Edward III ada empat hal yang mempengaruhi terlaksananya implementasi program antara lain: 1) Komunikasi, 2) Disposisi /sikap pelaksana, 3) Sumber daya, 4) Struktur Birokrasi. Implementasi adalah suatu kegiatan yang dimaksudkan untuk mengoperasikan sebuah program, dengan tiga kegiatan sebagai pilarnya, sebagaimana dinyatakan Jones yaitu: Organisasi, yaitu menyangkut pembentukan atau penataan kembali sumber daya, unit-unit dan metode untuk menjadikan program; Interpretasi, yaitu menafsirkan agar program menjadi rencana dan pengarahan yang tepat dan dapat diterima serta dilaksanakan; Aplikasi/penerapan, yaitu ketentuan rutin dari pelayanan,pembayaran atau lainnya yang disesuaikan dengan ujuan program (Suparman dkk, 2014).

Berdasarkan apa yang dikemukakan Winarno tersebut, menunjukkan bahwa efektivitas implementasi suatu kebijakan sangat ditentukan oleh perilaku birokrasi pelaksananya. Perilaku ini dipengaruhi oleh lingkungan kebijakan. Van Meter dan Van Horn, merumuskan sebuah abstraksi yang memperlihatkan hubungan antar berbagai faktor yang mempengaruhi hasil atau kinerja suatu kebijakan, dengan mambagi 6 (enam) indikator yang semuanya ini harus dicermati oleh seorang avaluator, yaitu: (1) kompetensi dan jumlah staf; (2) rentang dan derajat pengendalian; (3) dukungan politik yang dimiliki; (4) kekuatan Organisasi: (5) derajat Keterbukaan dan kebebasan komunikasi; (6) Keterkaitan dengan pembuat kebijakan. Keenam indikator tersebut, maka indikator terakhir menunjuk pada akses organisasi dalam mempengaruhi kebijakan. Kesemua indikator tersebut membentuk sikap pelaksana terhadap kebijakan yang mereka implementasikan dan akhirnya dapat menentukan seberapa tinggi kinerja kebijakannya (Kamaluddin 2018). Menurut Hogwood dan Gunn, untuk dapat mengimplementasikan kebijakan secara sempurna maka diperlukan beberapa persyaratan, antara lain:
a. Kondisi eksternal yang dihadapi oleh Badan/Instansi pelaksana;
b. Tersedia waktu dan sumber daya;
c. Keterpaduan sumber daya yang diperlukan
d. Implementasi didasarkan pada hubungan kausalitas yang handal
e. Hubungan kausalitas bersifat langsung dan hanya sedikit mata rantai penghubung;
f. Hubungan ketergantungan harus dapat diminimalkan;
g. Kesamaan persepsi dan kesepakatan terhadap tujuan;
h. Tugas-tugas diperinci dan diurutkan secara sistematis;
i. Komunikasi dan koordinasi yang baik;
j. Pihak-pihak yang berwenang dapat menuntut kepatuhan pihak lain (Kamaluddin, 2018).
Seperti yang telah tercantum dalam peraturan bupati magetan nomor 15 tahun 2019 tentang perubahan atas peraturan bupati nomor 7 tahun 2019 pengalokasian, pembagian, dan tata cara penyaluran alokasi dana desa kepada setiap desa di Kabupaten Magetan tahun 2019 bahwa alokasi dana 
untuk Desa Purwodadi adalah 471.775.530. Sedangkan dana yang dialokasikan desa dalam pelaksanaan gumelaring kadipaten adalah sebesar Rp 60.000.000.

Untuk mengetahui pengelolaan dana desa secara spesifik maka perlu dilakukan pengamatan dan perhatian dalam proses pelaksanaan sampai dengan evaluasi sehingga dapat diketahui gambaran bagaimana alokasi dana desa digunakan. Dari uraian tersebut, penulis tertarik untuk mengetahui bagaimana implementasi dana desa untuk kegiatan gumelaring kadipaten di Desa Purwodadi Kecamatan Barat Kabupaten Magetan.

Pasal 71 Undang-Undang Nomor 6 Tahun 2014 menjelaskan bahwa keuangan desa adalah semua hak dan kewajiban Desa yang dapat dinilai dengan uang serta segala sesuatu berupa uang dan barang yang berhubungan dengan pelaksanaan hak dan kewajiban desa. Dalam Peraturan Pemerintah Nomor 60 Tahun 2014 tentang Dana Desa yang bersumber dari APBN, Pasal 1 ayat 2 menjelaskan bahwa Dana Desa adalah dana yang bersumber dari Anggaran Pendapatan dan Belanja Negara yang diperuntukkan bagi Desa yang ditransfer melalui Anggaran Pendapatan dan Belanja Daerah Kabupaten/Kota dan digunakan untuk membiayai penyelenggaraan pemerintahan, pelaksanaan pembangunan, pembinaan kemasyarakatan, dan pemberdayaan masyarakat (Mustanir \& Darmiah, 2016).

Otonomi daerah sangat mendorong Pemerintah Desa untuk lebih memberdayakan masyarakat dan mengoptimalkan sumberdaya yang ada baik itu sumberdaya dari desa sendiri maupun dari luar. Salah satu sumberdaya dari luar desa yaitu alokasi dana dari Pemerintah Daerah yang disebut Alokasi Dana Desa. Adanya Alokasi Dana desa (ADD) tersebut, desa memiliki kewenangan untuk mengatur dan mengurus rumah tangganya sesuai dengan kewenangan yang diberikan, yang menyangkut peranan pemerintah desa sebagai penyelenggara pelayanan publik di desa dan sebagai tujuan dalam proses perencanaan dan pelaksanaan pembangunan daerah yang melibatkan masyarakat di tingkat desa. Untuk melaksanakan kewenangan tersebut, pemerintah desa memiliki sumber daya penerimaan yang digunakan untuk membiayai kegiatan yang dilakukan di desa. Salah satu hal yang penting untuk mendukung proses pelaksanaan pembangunan di setiap desa adalah adanya kepastian keuangan untuk pembiayaan (Dura 2018).

Dana Desa merupakan dana yang bersumber dari Anggaran Pendapatan dan Belanja Negara (APBN) yang diperuntukan bagi desa yang digunakan untuk membiayai penyelenggaraan pemerintahan, pembangunan, pembinaan, dan pemberdayaan masyarakat. 12 Pengalokasian Dana Desa merupakan pelaksanaan amanat UU Desa dan Peraturan Pemerintah Nomor 60 Tahun 2014 tentang Dana Desa yang Bersumber dari Anggaran Pendapatan dan Belanja Negara, yang bertujuan untuk meningkatkan kesejahteraan dan pemerataan pembangunan, serta mengatasi kesenjangan antara desa dan kota melalui perbaikan pelayana publik, sarana infrastruktur, dan peningkatan perekonomian. Dana Desa merupakan anggaran belanja pemerintah dengan lebih mengefektifkan program yang berbasis desa secara merata dan berkeadilan (I Putu Eva Ardiana; I Ketut Tjukup 2014).

Keuangan desa, awal pengaturannya melalui Peraturan Menteri dalam Negeri No. 113 Tahun 2014 tentang Pengelolaan Keuangan Desa.Permendagri tersebut bertujuan untuk memudahkan dalam pelaksanaan pengelolaan keuangan desa, sehingga tidak menimbulkan multitafsir dalam penerapannya.Dengan demikian desa dapat mewujudkan pengelolaan keuangan yang efektif dan efisien. Disamping itu diharapkan dapat diwujudkan tata kelola pemerintahan desa yang baik, yang memiliki tiga pilar utama yaitu transparansi , akuntabilitas dan partis ipatif. Oleh karenanya , proses dan mekanisme penyusunan APBDesa yang diatur dalam Permendagri tersebut akan menjelaskan siapa yang bertanggungjawab, dan kepada siapa bertanggungjawab, dan bagaimana cara pertanggung jawabannya. Berikut ini adalah gambar 4 yang menunjukkan siklus Pengelolaan Keuangan Desa. Setiap tahapan proses pengelolaan keuangan desa tersebut memiliki aturan - aturan yang harus dipahami dan dilaksanakan 
sesuai dengan batasan waktu yang telah ditentukan (Kementerian Keuangan Republik Indonesia, 2016) (Khoiriah, Siti, Meylina 2017).

\section{B. METODE PENELITIAN}

Pada penelitian ini peneliti menggunakan pendekatan kualitatif yaitu suatu gejala yang bersifat alamiah sehingga peneliti terjun langsung kelapangan untuk menggali data mulai dari observasi, wawancara, dokumentasi, cuplikan tertulis dari dokumen dan catatan lapangan tidak dituangkan dalam bentuk bilangan statistik. Peneliti melakukananalisis data dengan memperkaya informasi dan melalui analisis komparasi sepanjang tidak menghilangkan data aslinya.

\section{HASIL DAN ANALISIS}

Festival Budaya Gumelaring Kadipaten Purwodadi ini, Merupakan Destinasi Wisata yanga Luar Biasa, Karena apa Yang di Suguhkan Benar-Benar Mempuyai Ke unikan dan Berkarakter, dan mempunyai Seni yang Indah. Bambang Berharap Kebudayaan ini nanti bisa tumbuh kembang yang akhirnya menjadi kebanggaan bangsa khususnya Budaya Jawa yang Adi luhung. Kegiatan ini di laksanakan dengan Tujuan upaya untuk ikut serta melestarikan budaya bangsa, sekaligus sarana dalam rangka menggerakan ekonomi Masyarakat yang ada di desanya, Selain itu Juga Berharap Ke depan Desa Purwodadi bisa disyahkan dan dijadikan desa wisata oleh Pemkab Kab Magetan (Kepala Dinas Pariwisata Magetan Bambang Setiawan 2018).

Situs berpotensi cagar budaya Benteng Kadipaten Purwodadi dan sejarah Kadipaten Purwodadi hingga saat ini masihbelum diketahui masyarakat Kabupaten Magetan. Hal ini dikarenakan hingga saat ini situs tersebut belum ditetapkan sebagai situs cagar budaya Kabupaten Magetan dan belum pernah dilakukan riset sejarah dan riset arkeologi yang mendalam. Oleh karena itu, kegiatan Gumelaring Kadipaten Purwodadi ( GKP) - 2019 ini bertujuan mengangkat kembali potensi yang ada di wilayah bekas Kadipaten Purwodadi dengan menampilkan semua potensi seni dan budaya di wilayah magetan, baik berupa seni budaya trsadisional, modern maupun kontenporer sekaligus memelihara dan menyelamatkan aset bangsa berupa peninggalan sejarah Benteng Kadipaten Purwodadi dan menyambung kembali missing link antara generasi tua dan generasi muda (Proposal_Festival_Food 2019).

Gambar 2 Diagram Jenis Pengunjung

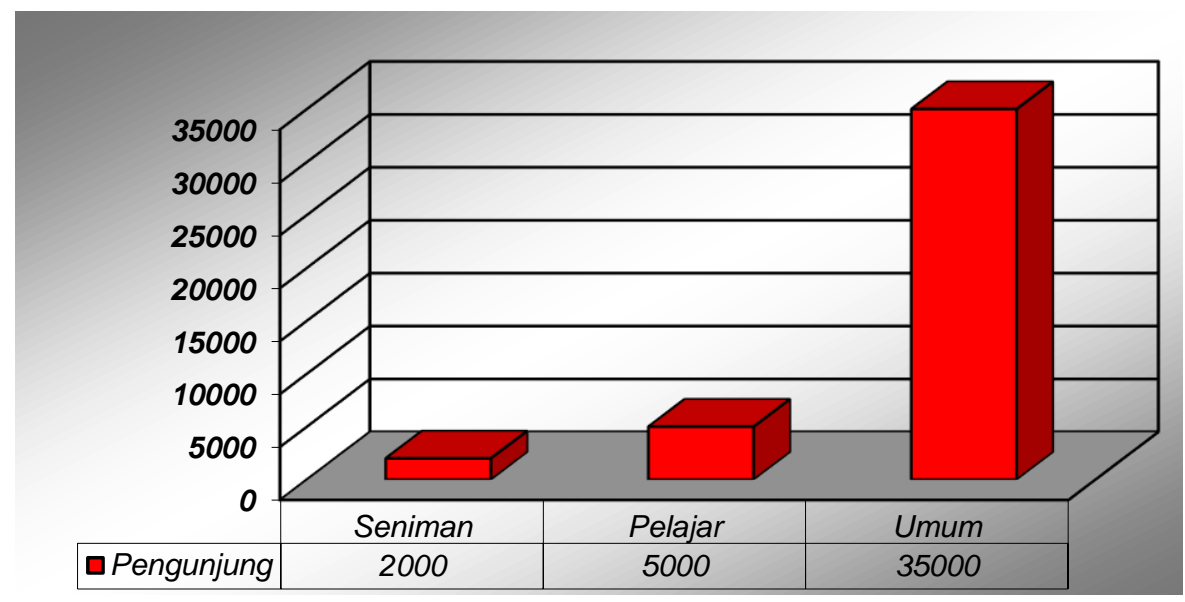

Sumber : Diolah dari (Proposal_Festival_Food 2019) 
Berdasarkan penyajian data di atas dapat di analisis bahwa implementasi dana desa purwodai cukup membantu dalam kegiatan Gumelaring Kadipaten,akan tetapi belum bisa memenuhi segala aspek kebutuhan dan anggaran yang telah di ajukan oleh pihak penyelenggara kegiatan gumelaring kadipatem. Namun dari sisi perencanan dan teknis pembukuan sudah sesuai dengan petunjuk penglolaan alokasi dana desa karena pengeluaran dana tersebut juga disertai denganya lembar pertanggung jawaban (LPJ).

Awal mula adanya event budaya Gumelaring Kadipaten adalah pada tahun 2016. Kegiatan ini bertujuan untuk melestarikan sejarah yang ada di desa purwodadi. Ditengah desa purwodadi terdapat sebuah peninggalan sejarah yakni kadipaten yang merupakan sebuah benteng pertahanan yang megah dan menjadi pusat pemerintahan yang sangat ramai. Adanya peninggalan sejarah tersebut merupakan sesuatu yang patut untuk dilestarikan bersama, salah satu wujud pelestarian sejarah adalah dengan diselenggarakannya festival Gumelaring Kadipaten. Dengan dibantu anggaran oleh desa melalui dana yang di ambil dari dana desa yang mana dana tersebut untuk membantu meringankan anggaran yang di angggarkan oleh pihak panitia acara gumelaring kadipaten sebesar Rp. 60.000.000 agar digunakan dengan semestinya, seperti proposal yang telah di ajukan oleh pihak panitia. Hal ini menunjukkan bahwa pihak desa sangatlah mendukung adanya pelestarian situs bersejarah di Desa Purwodadi.

Nilai sejarah kadipaten sudah ada sejak dahulu dan berdasarkan sejarah pula disenbutkan bahwa pangeran diponegoro pernah berada di desa Purwodadi. Adapun situs kadipaten dan peninggalan lainnya adalah peninggalan pangeran diponegoro. Tujuan utama diadakannya Gumelaring Kadipaten adalah agar masyarakat bisa mengenal situs sejarah ini dan dapat dijadikan cagar budaya. Dengan peninggalan tersebut bisa menjadikan edukasi masyarakat dan pengunjung yang datang. Tujuan lain dari Gumelaring Kadipaten adalah mempromosikan wisata dan budaya dalam acara yang diselenggarakan seperti Seni tari, seni musik, seni lukis, Seni tradisional lokal (batik, tosan aji, wayang kulit, jedor, hadroh, ketoprak, reog, barongsai, ledug), Kuliner tradisional handy craft, Seni instalasi dan dekorasi, Seni tata rias dan kostum, Tour Wisata Sejarah Kadipaten Purwodadi dan Pasar rakyat.

Dalam pelaksanaan Gumelaring Kadipaten pihak panitia membuat MOU dengan pihak pemerintah desa agar terjalin hubungan yang baik. Peran desa dalam terselenggaranya Gumelaring Kadipaten adalah mensupport kegiatan dengan membantu pendanaan yang dibutuhkan oleh panitia penyelenggara kegiatan Gumelaring Kadipaten.

Penerapan prinsip akuntabilitas pengelolaan Alokasi Dana Desa (ADD) dimulai dari tahap perencanaan, pelaksanaan semua kegiatan, dan setelah kegiatan sehingga pengelolaan ADD diharapkan dapat dipertanggungjawabkan. Anggaran Alokasi Dana Desa (ADD) yang sesuai dengan kebutuhan merupakan salah satu bentuk desentralisasi guna mendorong good governance karena mendekatkan negara kepada masyarakat sekaligus meningkatkan partisipasi masyarakat yang akhirnya mendorong akuntabilitas dan transparansi. (Febri Arifiyanto and Kurrohman 2014).

Menurut Hogwood dan Gunn untuk dapat mengimplementasikan kebijakan secara sempurna maka diperlukan beberapa persyaratan, antara lain:

a. kondisi eksternal yang dihadapi oleh Badan/Instansi pelaksana

b. tersedia waktu dan sumber daya

c. keterpaduan sumber daya yang diperlukan

d. implementasi didasarkan pada hubungan kausalitas yang handal

e. hubungan kausalitas bersifat langsung dan hanya sedikit mata rantai penghubung

f. hubungan ketergantungan harus dapat diminimalkan

g. kesamaan persepsi dan kesepakatan terhadap tujuan

h. tugas-tugas diperinci dan diurutkan secara sistematis

i. komunikasi dan koordinasi yang baik

j. pihak-pihak yang berwenang dapat menuntut kepatuhan pihak lain (Wisakti 2008). 
Peran Desa Purwodadi dalam melestarikan budaya dan mengangkat nilai sejarah dari kadipaten purwodadi dalam acara gumelaring kadipaten yaitu dengan mensupport anggaran yaang di ambil dari dana desa untuk kebutuhan acara Gumelaring Kadipaten sesuai dengan apa yang panitia anggarkan dan membuatkan LPJ sebagai bukti-bukti pengeluaran atau belanja tersebut untuk kelengkapan administrasi sesuai perundang-undangan yang berlaku.

Pihak panitia gumelaring kadipaten mengajukan proposal kepada desa purwodadi untuk diminta mensupport dana kegiatan gumelaring kadipaten, adapun anggaran yang dibutuhkan untuk acara gumelaring kadipaten ditampilam pada tabel 10:

Tabel 10 Total Anggaran Proposal

\begin{tabular}{l|c|}
\hline \multicolumn{2}{|c|}{ Total Anggaran } \\
\hline Kesekretariatan & $2,830,000$ \\
\hline Perlengkapan Festival & $44,250,000$ \\
\hline Kelengkapan Acara & $99,000,000$ \\
\hline Transportasi Acara & $4,000,000$ \\
\hline Publikasi Acara & $2,845,000$ \\
\hline Konsumsi Acara & $27,250,000$ \\
\hline Dokumentasi & $5,000,000$ \\
\hline \multicolumn{1}{c|}{ Total } & $\mathbf{1 8 5 , 1 7 5 , 0 0 0}$ \\
\hline
\end{tabular}

\section{Sumber : Diolah dari (Proposal_Festival_Food 2019)}

Namun pihak Desa Purwodadi tidak bisa menanggung semua total anggaran yang dibutuhkan untuk acara gumelaring kadipaten tersebut dikarenakan anggaran yang besar dan juga ada batas maksimal untuk mengeluarkan sebuah anggaran untuk pendanaan sebuah acara, pihak desa hanya bisa mensupport dana sebesar Rp. 60.000.000 untuk kegiatan Gumelaring Kadipaten yang dana tersebut di ambil dari dana desa yang dimiliki Desa Purwodadi yang pastinya jika ada pengeluaran anggaran dana desa harus disertai pembuatan lembar pertanggung jawaban (LPJ) untuk syarat administrasi pengeluaran dana desa yang sah untuk kegiatan Gumelaring Kadipaten karena telah mengeluarkan dana desa sebesar nominal tersebut.

\section{SIMPULAN}

Dana Desa merupakan salahs atu instrument yang dapat dimanfaatkan desa untuk membiayai aktifitas desa, seperti program pemberdayaan masyarakat ataupun program pengembangan wilayah, salah satu contohnya adalah penggunaan dana desa untuk aktifitas wisata sekaligus pelestarian budaya, yang di lakukan oleh Desa Purwodadi Kecamatan Babat Kabupaten Magetan, hal ini dilakukan sebagai bentuk apresiasi pemerintah desa dnegan keberadaan situs bersejarah, diharapkan kegiatan Gumeraling Kadipaten ini bisa menjadi pemantik sektor wisata. 


\section{REFERENSI}

Dura, Justita. 2018. "Pengaruh Akuntabilitas Pengelolaan Keuangan Alokasi Dana Desa, Kebijakan Desa, Dan Kelembagaan Desa Terhadap Kesejahteraan Masyarakat." Jurnal Ilmiah Bisnis dan Ekonomi Asia 10(2): 26-32.

Garis, Regi Refian. 2017. Analisis Implementasi 4 Program Prioritas Kementrian Desa Pembangunan Daerah Tertinggal dan Transmigrasi. Moderat: Jurnal Ilmiah Ilmu Pemerintahan.

Hasman, Rasmah. 2015. Implementasi Kebijakan Alokasi Dana Desa di Kecamatan Kinovaro Kabupaten Sigi. E-jurnal Katalogis, Vol 3: No 11.

Hertati, Diana dan Lukman Arif. 2018. Implementasi Kebijakan Pengelolaan Dana Desa di Desa Pejambon Kabupaten Bojonegoro Jawa Timur. Journal of Economics, Business, and Government Challenges, Vol 1: No 1.

I Putu Eva Ardiana; I Ketut Tjukup. 2014. “Desa Dalam Kaitannya Dengan Otonomi Desa Berdasarkan Undang-Undang Nomor 6 Tahun 2014 Tentang Desa." : 1-18.

Kamaluddin. 2018. "Implementasi Kebijakan Alokasi Dana Desa Di Wilayah Desa Maria Kecamatan Wawo Kabupaten Bima." Jurnal Komunikasi dan Kebudayaan 5: 15-33.

Kepala Dinas Pariwisata Magetan Bambang Setiawan. 2018. "Gumelaring Kadipaten Purwodadi Magetan."

Khoiriah, Siti, Meylina, Utia. 2017. “Analisis Sistem Pengelolaan Dana Desa Berdasarkan.” Jurnal Masalah-Masalah Hukum 66(1): 20-29.

Mustanir, Ahmad dan Darmiah. 2016. Implementasi Kebijakan Dana Desa dan Partisipasi Masyarakat dalam Pembangunan di Desa Teteaji Kecamatan Limpoe Kabupaten Sidenreng Rappang. Jurnal Politik Profetik, Vol 04: No 2.

"Proposal_Festival_Food." 2019.

Suparman, Dedi Kusnadi, and Dwi Haryono. 2014. "Implementasi Program Alokasi Dana Desa Di Kecamatan Sukadana Kabupaten Kayong Utara." Tesis PMIS-UNTAN-PSIAN: 1-20. 